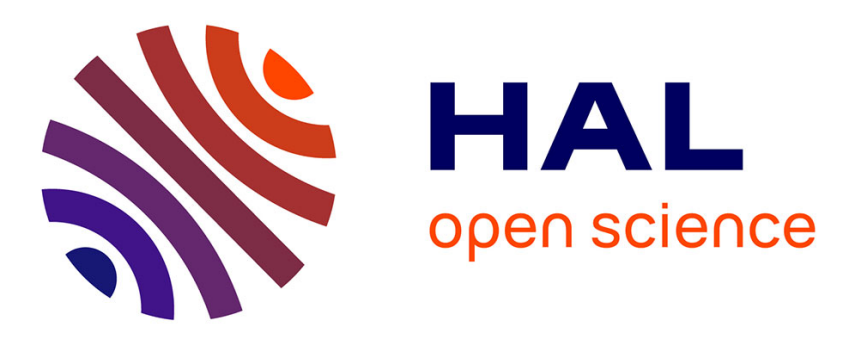

\title{
Knowledge-based approaches for river basin management
}

P. Mikulecký, K. Ol?evi?ová, D. Ponce

\section{To cite this version:}

P. Mikulecký, K. Ol?evi?ová, D. Ponce. Knowledge-based approaches for river basin management. Hydrology and Earth System Sciences Discussions, 2007, 4 (3), pp.1999-2033. hal-00298854

\section{HAL Id: hal-00298854 \\ https://hal.science/hal-00298854}

Submitted on 29 Jun 2007

HAL is a multi-disciplinary open access archive for the deposit and dissemination of scientific research documents, whether they are published or not. The documents may come from teaching and research institutions in France or abroad, or from public or private research centers.
L'archive ouverte pluridisciplinaire HAL, est destinée au dépôt et à la diffusion de documents scientifiques de niveau recherche, publiés ou non, émanant des établissements d'enseignement et de recherche français ou étrangers, des laboratoires publics ou privés. 
Hydrol. Earth Syst. Sci. Discuss., 4, 1999-2033, 2007 www.hydrol-earth-syst-sci-discuss.net/4/1999/2007/

(C) Author(s) 2007. This work is licensed under a Creative Commons License.
Hydrology and

Earth System

Sciences

Discussions

Papers published in Hydrology and Earth System Sciences Discussions are under open-access review for the journal Hydrology and Earth System Sciences

\section{Knowledge-based approaches for river basin management}

P. Mikulecký ${ }^{1}$, K. Olševičová ${ }^{1}$, and D. Ponce ${ }^{1}$

${ }^{1}$ Faculty of Informatics and Management, University of Hradec Králové, Rokitanského 62, Hradec Králové 500 03, Czech Republic

Received: 14 May 2007 - Accepted: 14 May 2007 - Published: 29 June 2007

Correspondence to: P. Mikulecký (peter.mikulecky@uhk.cz)

\section{HESSD}

4, 1999-2033, 2007

Knowledge-based approaches for river basin management

P. Mikulecký et al.

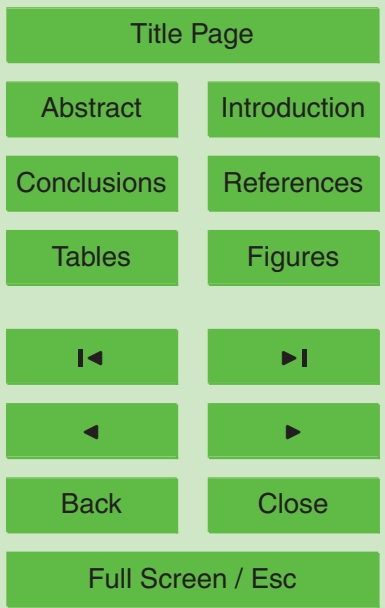

Printer-friendly Version

Interactive Discussion 


\section{Abstract}

Rare attempts to use knowledge technologies and other relevant approaches are found in the river basin management. Some applications of expert systems as well as utilization of soft computing techniques (as neural networks or genetic algorithms) are 5 known in an experimental level. Knowledge management approaches still have not been used at all. In this paper we discuss knowledge-based approaches in the river basin management as a difficult yet important direction which could be proven to be helpful. We summarize the research done in the scope of the AQUIN project, one of first Czech knowledge management projects in the river basin management. The 10 project was initiated by the water management company in Pilsen, where dispatchers make decisions about manipulations on the reservoir Nýrsko, the strategic source of drinking water for inhabitants of Pilsen. The project aim was to support dispatchers' decision making under a high degree of uncertainty or data shortage. The research is continued in the scope of a new project AQUINpro, planned for the period of 2006 to 152008.

\section{Introduction}

There were only a few experiments with usage of knowledge technologies and other relevant approaches in the field of river basin management (see e.g. Baeza et al., 1998; Nacházel and Toman 1995, 1997). Knowledge management approaches have not been used often, some first attempts can be found in Mikulecký (2003a, b), Ponce and Toman (2003a, b), Mikulecký (2004) and Olševičová and Ponce (2004).

Knowledge management (see, e.g. Davenport and Prusak, 1998, as well as plenty of other sources) applies systematic approaches to find, understand, organize, store, disseminate, and use knowledge in order to better understand various processes, problems, relationships, etc., and in order to create new value. Informally, knowledge management can really be used for managing knowledge from any important but somehow
HESSD

4, 1999-2033, 2007

\section{Knowledge-based approaches for river basin management \\ P. Mikulecký et al.}

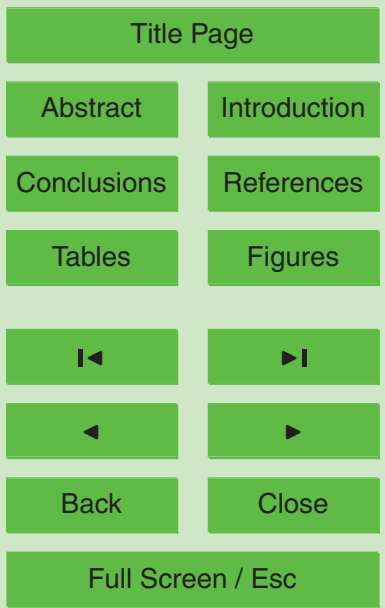

Printer-friendly Version

Interactive Discussion 
restricted area, usually rich on knowledge. The simplest approach is based on collecting all the important knowledge from certain area (e.g. as managing a particular river basin), organizing and representing this knowledge in an appropriate knowledge-based tool (e.g. a knowledge base of a knowledge-based system), sharing this repository of 5 knowledge throughout the organization entitled to use it (e.g. the river basin control room).

Water management, or especially river basin management, to be efficiently applied in everyday practice, needs knowledge, as any other knowledge intensive activity. Knowledge is usually possessed only by a narrow group of specialists (experts in the area, 10 e.g. river basin dispatchers) who know when, how, and what must be done in order to provide proper water supply, or to cope with a dramatic consequences of floods. This knowledge, as it happens with experts everywhere, may not be available whenever it is necessary for various reasons:

- experts need not be always available when necessary,

- experts can suffer from common human problems, or suddenly their knowledge can be lost because of their mortality, or retirement,

- experts can differ in their opinions on how to solve a particular situation, etc.

All of these and other reasons are in favour of the opinion that various knowledge management solutions using proper knowledge-based tools, which have already proven their usefulness in other areas, could be very beneficial also in water management.

From the engineering point of view, the experts' reasoning about problems and decision making about suitable solutions is understood as manipulating with specific data, mathematical models of the real situation, simulations, etc. In water management domain, we can think of mathematical modelling of hydrological data, mathematical models for optimization and control of reservoirs seen from the hydrological aspects, models of optimized water management in dry periods, rainfall-runoff terms for outflow forecasting, or elementary models of pollution effusing in rivers.

\section{HESSD}

4, 1999-2033, 2007

\section{Knowledge-based approaches for river basin management}

P. Mikulecký et al.

Title Page

Abstract

Introduction

Conclusions

Tables

References

Figures

14

$\rightarrow$

4

Back

Close

Full Screen / Esc

Printer-friendly Version

Interactive Discussion 
In case of inaccessibility, incompleteness, or incorrectness of data as well as in other situations with high degree of uncertainty, experts still are able to make decisions, while all the classical approaches fail; neither algorithmic solution nor exact formulae can be used. The obstacles related to the lack of data can be solved by employing 5 suitable approaches from the area of soft computing; some experience in this direction can be found in Nacházel and Toman $(1995,1997)$. However, these approaches are not always fully satisfying. Then the space for the utilization of the knowledge-based technologies and for knowledge management opens.

\section{Knowledge-based approaches and knowledge management}

10 As mentioned frequently, knowledge management focuses on "doing the right thing" instead of "doing things right." Knowledge management can be seen as a framework within which the organization views all its processes as knowledge processes. In this view, all activities in the organization involve creation, dissemination, renewal, and application of knowledge toward organizational persistence (sustenance je vyživa, strava) 15 and survival.

The two main types of knowledge are tacit and explicit knowledge. Tacit knowledge tends to reside within the heads of its owners (knowers), while explicit knowledge is usually contained within tangible media. The most important consequence of this division is that knowledge must become explicit in order to be shareable. However, the most valuable knowledge within an organization uses to be tacit. Highly skilled, experienced, and expert individuals are very often unable to articulate their know-how easily and understandably.

The processes, that are oriented on capturing the valuable tacit knowledge, and on its transformation into explicit knowledge and its subsequent organization, storage and

further dissemination, are usually characterized and visualised as the knowledge life cycle. There is a couple of approaches to the knowledge life cycle definition. However, each of them has to encompass the capture, creation, representation, sharing, access-

\section{HESSD}

4, 1999-2033, 2007

Knowledge-based approaches for river basin management

P. Mikulecký et al.

Title Page

Abstract Introduction

Conclusions

Tables

References

Figures

14

$\rightarrow$

4

Back

Close

Full Screen / Esc

Printer-friendly Version

Interactive Discussion 
ing, application as well as reuse of knowledge within an organization, or even among organizations.

According to Dalkir (2005), the four major approaches to knowledge life cycles are presented by Meyer and Zack (1996), Bukowitz and Williams (2000), McElroy (2003), 5 and Wiig (1993). Let us characterize two of them briefly.

Possibly the oldest of the knowledge life-cycle approaches, formulated by Wiig (1993), focuses on the three conditions that need to be present for any organization to conduct its main activities successfully: it must have a business (or products or services) and customers; it must have resources (people, capital, and facilities); and it 10 must have the ability to act. Especially this third point is stressed in the life cycle by Wiig. The cycle addresses how knowledge is built and used by individuals or by organizations. The four main steps in this cycle are building, holding, pooling and applying knowledge. As the matter of fact, the cycle is more complicated than its appearance shows. It addresses a broad range of learning from all types of sources: personal experience, formal education or training, peers, and also intelligence. The knowledge can be then held either within the heads of workers, or in some tangible form (books, databases).

When going deeper into the four main steps of the knowledge life-cycle by Wiig, we can identify a number of major activities from which the main steps are composed. Building knowledge means to accomplish the five main activities: obtain, analyse, reconstruct/synthesize, codify/model and organize knowledge. Holding knowledge consists of remembering, accumulating knowledge in repositories, and archiving it. Examples of tacit knowledge residing held by organizations include first of all tacit knowledge remaining in the minds of individuals, which may be elicited using knowledge engineer25 ing methods and embedded in digital knowledge bases or other types of repositories. However, knowledge in organizations can be also documented in the form of research reports or technical papers.

Knowledge pooling consists of coordinating, assembling, and accessing and retrieving knowledge. These activities lead to fulfilment of the main aim of knowledge man-

HESSD

4, 1999-2033, 2007

\section{Knowledge-based approaches for river basin management}

P. Mikulecký et al.

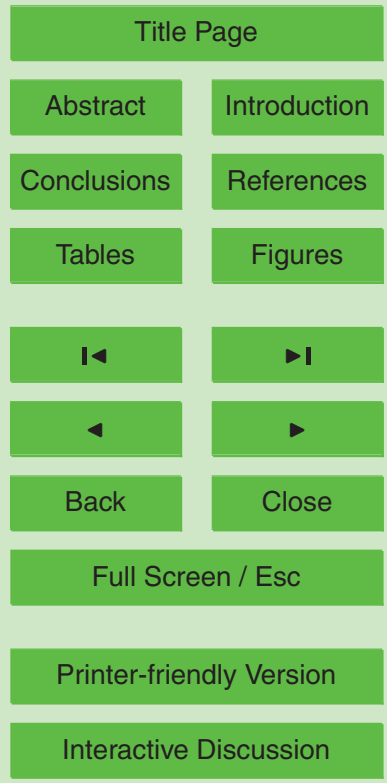

EGU 
agement activities - sharing the valuable knowledge throughout the organization. And finally, there are plenty of ways how to apply the knowledge in an organization.

The knowledge life-cycle by Meyer and Zack is derived from work on design and development of information products. Their life cycle consists of five phases: acquisition, 5 refinement, storage/retrieval, distribution, and presentation. Acquisition addresses the issues regarding sources of "raw" knowledge, with an accent on the quality of source data. Refinement is the primary source of added value; it refers also to cleaning up or standardizing acquired knowledge. Storage and retrieval form a bridge between acquisition and refinement phases which lead to a contribution to created knowledge 10 repository, and the phase of exploitation of the valuable knowledge in its reuse. Storage may be physical (in printed materials), or more often digital, exploitable in a computer network. Distribution then describes how the product is delivered to the end user of shared knowledge, and the final step, presentation or use, can be then fulfilled by the knowledge users. When applying the shared knowledge, usually a new knowledge is 15 created, that may be added to that already shared. It means that a new cycle begins, and all the phases can be repeated.

\subsection{Knowledge identification}

First of all, if we intend to apply some knowledge management approaches, it is inevitable to identify necessary knowledge. This phase is preceding the above men20 tioned major stages of knowledge life cycle. It is essential to decide what knowledge is already available, and where are the sources of other knowledge, which seems to be exploitable for further use.

In order to distinguish various types of knowledge according to their sources, Davenport and Prusak (1998) suggested five types of knowledge:

- acquired knowledge comes from outside the organization; here originality is often less important than usefulness; various books or textbooks are typical examples of such acquired knowledge;

\section{HESSD}

4, 1999-2033, 2007

\section{Knowledge-based approaches for river basin management}

P. Mikulecký et al.

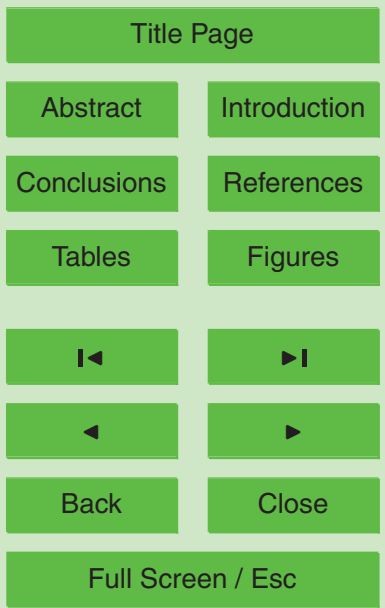

Printer-friendly Version

Interactive Discussion 
- dedicated knowledge comes from staff members or entire departments in the organization, and usually is developed within the institution for a special purpose; these dedicated resources are usually protected from competitive pressures in order to develop profitable products;

- fusion knowledge is created by bringing together people with different perspectives and/or different background in order to work on the same project; crossfunctional teams are becoming popular in numerous institutions and are good examples of fusion;

- adaptation is knowledge that results from responding to new processes or technologies in the market place; the expansion of on-line instruction offered by higher education or other institutions is an example of adaptation;

- knowledge networking is knowledge in which people share information with one another formally or informally; knowledge networking often occurs within disciplines, for example, an institutional researcher communicating with another.

15 Knowledge sources vary highly in their profundity. E.g. in water reservoir management, some sources of the knowledge have a form of professional textbook capturing the basic domain knowledge. Other sources consist of lookup-tables and so-called manipulation graphs that are based on analysis of historical data characterizing the river and the reservoir behaviour. The most valuable is heuristic knowledge of operators 20 who gained remarkable insight to the behaviour of the whole river basin ecosystem and related control system after years spent operating it.

When identifying potential knowledge sources for the purpose of the knowledgebased system development, an important criterion is the availability of the source. Expectations and the reality do not match perfectly and some eventual sources of knowl-

\section{HESSD}

4, 1999-2033, 2007

\section{Knowledge-based approaches for river basin management}

P. Mikulecký et al.

Title Page

Abstract

Introduction

Conclusions

Tables

References

Figures

14

4

Back

Close

Printer-friendly Version

Interactive Discussion 
analysis reports that can only be purchased obeying some financial constraints of the river basin company.

An important aspect of the whole process is having co-operative experts, willing to participate in the project, who do not hesitate to share their knowledge with the artificial 5 system deployed. This is usually one of the hardest conditions which must be fulfilled in order to ensure the success of the knowledge management project.

\subsection{Knowledge capture and creation}

In an organization, new knowledge is usually created when a problem is solved in a particular problem area. The initial knowledge is combined with this new knowledge based on ongoing experience creating thus an updated knowledge for knowledge sharing. Unfortunately, most organizations have a very competitive culture which is not in favour of knowledge sharing. Prevailing attitude here is "knowledge is power". In such an organization one cannot speak about efficient knowledge exploitation and the firm's goals are not achieved on a desirable level.

15 Existing knowledge, in order to be shared, must be captured from their sources. The most valuable knowledge sources are human experts, who are very valuable for organizations, and therefore not easily accessible. There is a plenty of very sophisticated and psychologically elaborated ways of tacit knowledge capturing from human experts. Further information can be found e.g. in Awad and Ghaziri (2004).

\subsection{Knowledge sharing and dissemination}

According to Awad and Ghaziri (2004), knowledge sharing is more than simply knowing the right thing to do. Knowledge sharing is making available what is known now. Knowledge transfer is a prerequisite for knowledge sharing for competitive advantage, performance and profitability. Knowledge in order to be shared must be transferred from different sources, like knowledge bases, databases, or various Internet sources. Shared knowledge must be disseminated then in order to be useful for those who need
HESSD

4, 1999-2033, 2007

\section{Knowledge-based approaches for river basin management}

P. Mikulecký et al.

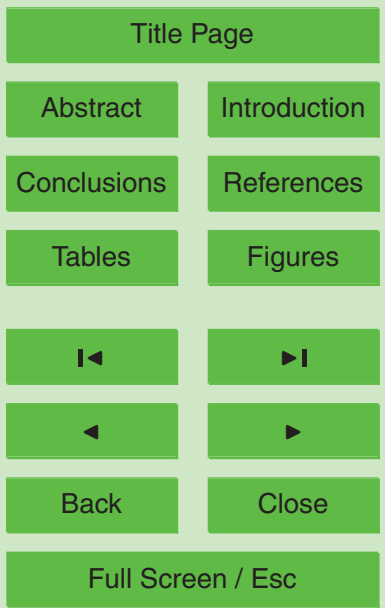

Printer-friendly Version

Interactive Discussion 
it. Usual way of knowledge dissemination in an organization is via the Intranet, or various sophisticated software for teamwork support. Communities of practice play an especially important role here (see Dalkir, 2005 or Wenger, 2002; McDermott, and Snyder, 2002).

\section{$5 \quad 2.4$ Knowledge acquisition and application}

As Dalkir (2005) points out, knowledge management typically addresses one of two general objectives: knowledge reuse to promote efficiency and innovation to introduce more effective ways of doing things. Knowledge application refers then to the actual use of knowledge that has been captured or created (and thus acquired) and put into 10 the knowledge life cycle.

Knowledge is eventually made accessible to all the knowledge workers in the organization via networked computer infrastructure. Implicitly it is assumed that the acquired and shared knowledge is going to be used and applied. Not always this is true, and a number of barriers and ways how to overcome them have been studied and invented, 15 see for instance Dalkir (2005), Davenport and Prusak (1998), or Awad and Ghaziri (2004).

\section{Knowledge technologies applications in water management}

The area of expert systems seems to be up to now the most successful application outcome of the knowledge technologies research. Applications of expert systems for control of complex closed systems blocs like water treatment plants and wastewater plants are designed and utilized also in water resources management in the world. Expert systems that evaluate ecological impacts of different constructions are another type of their utilization. The largest utilization of expert systems is in medicine (diagnostic systems), in the control of complex technological industry processes, in energy
HESSD

4, 1999-2033, 2007

Knowledge-based approaches for river basin management

P. Mikulecký et al.

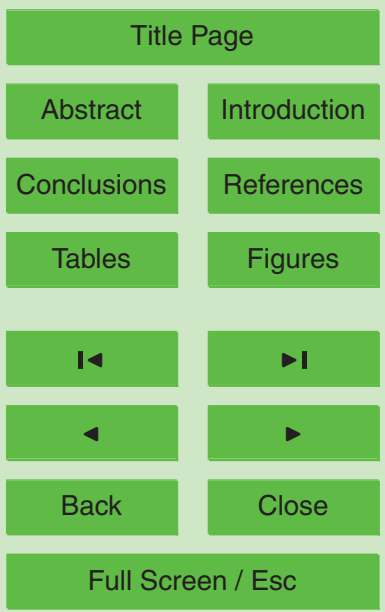

Printer-friendly Version

Interactive Discussion 


\subsection{Expert systems for forecasting and recommendation}

Intelligent system for fire risk forecasting and for fire fight management in Galicia is reported by Alonso-Betanzos et al. (2003). The system performs three tasks: it forecasts formation of forest fires, monitors existing fires till their complete extinction, and

5 it assists to planning of burnt areas regeneration. Completion of these tasks is done in two components. Neural network was constructed for forecasting of forest fire formation and knowledge-based system was created for fire monitoring and for assistance to regeneration planning.

The area of Galicia covered by the intelligent system is divided into 360 squares of $10 \times 10 \mathrm{~km}^{2}$. For each of these squares the neural network calculates daily risk of forest fire formation. The inputs of the neural network are six variables describing one square of the given area. These variables are: temperature of the given day and those of two previous days, daily humidity, daily rainfall and forest history. Historical data concerning these variables registered by five meteorological stations during the years

15 1988-2001 and their extrapolations for the whole area were used for the purposes of the neural network training. When using the neural network, daily forecasted values of these variables are used.

The knowledge-based system for fire monitoring and assistance to burnt areas regeneration was developed according to CommonKADS methodology (Schreiber et al., 2002). Based on the analysis of the fire fights processes, a set of knowledge-intensive tasks was identified: examination of fire diffusion, examination of fire control difficulty, fire classification, general fire fighting recommendation selection, fire fighting action planning, fire consequences analysis, regeneration criteria evaluation, and setting of recuperation actions priorities. Collaboration with experts from fire fighting organization of Galicia and from silviculture research centre of Lourizáno enabled to gain knowledge necessary for solution of the tasks mentioned above. This knowledge was captured in conceptual model which describes solution of the tasks using knowledge organized into rules. The resulting knowledge-based system was implemented in three programming

\section{HESSD}

4, 1999-2033, 2007

\section{Knowledge-based approaches for river basin management}

P. Mikulecký et al.

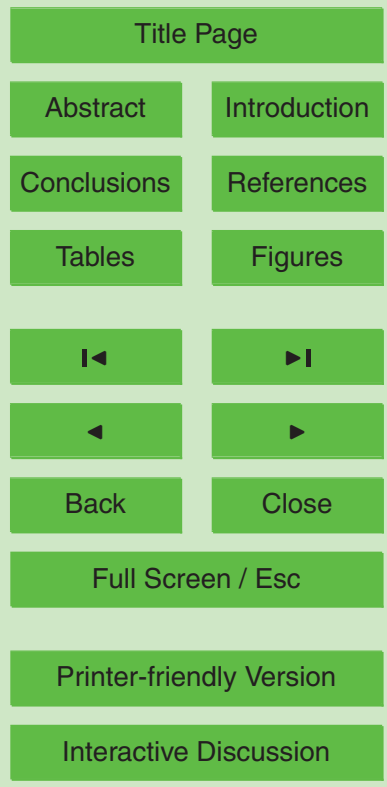

EGU 
tools: rule-based system CLIPS (C Language Integrated Production System) (CLIPS website, 2007) was used for the conceptual model, DELPHI was used for user interface and Paradox format was used for databases of historical and meteorological data.

The project terminated with a prototype which was supposed to be tested in lab 5 conditions and in real conditions, and which was supposed to be tuned for needs of real application environment.

\subsection{Expert systems in diagnostics}

Knowledge-based system for diagnosis of insufficient flocculation of activated sludge is reported by Comas et al. (2003). The system is implemented in G2 (Gensym website, 2007) and it is run in real conditions in waste water treatment plant in Granollers, Spain. The waste water treatment plant performs preliminary, primary and secondary treatment of domestic and industrial waste water in such a way that all organic matter, suspended solid matter and nitrogen are removed.

Knowledge-based solution meant creation of decision tree of deflocculation problem solution, implementation of decis

Creation of the decision tree was based on analysis of historical on-line and off-line data and on interviews with experts. Analyzed data cover data supplied by sensors, sample analyses, microscopic tests of sludge and daily macroscopic observation of the water treatment plant. Technique of knowledge discovery from data was used for identification of indicator variables which are the most relevant for operational states of the plant. These indicator variables were statistically analysed and qualitative warning values and deflocculation symptoms scales were formulated.

Interviews with experts served for identification of reasoning involved in defloccula25 tion diagnosis as well as in specific particular and general procedures applicable in certain situations. These symptoms, facts, relations and methods used by experts were represented in the form of decision tree. For each branch of decision tree a rule was created which was implemented in G2 environment.

HESSD

4, 1999-2033, 2007

\section{Knowledge-based approaches for river basin management}

P. Mikulecký et al.

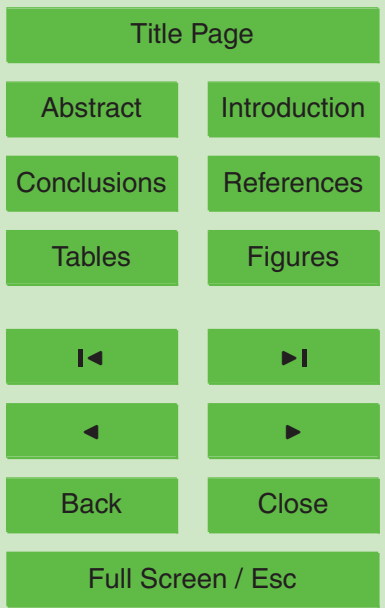

Printer-friendly Version

Interactive Discussion 
Validation of knowledge-based system was done by testing in laboratort conditions, later on by launching in testing operation. Laboratory off-line tests were performed based on a selection of historical data. Expert system was also tried out on a set of cases which were not recorded in the historical data. The expert system was launched 5 in testing mode as a real-time decision support system and it was integrated with the control system of waste water treatment plant. During the testing operation some weak point in its reasoning were detected and the knowledge base was refined, modified or improved in order to detect unexpected errors and to make correct decisions in new situations.

\subsection{Expert systems for planning and optimization}

The study of Mundo et al. (1995) reports on knowledge-based system for optimization of irrigation water supply for specific crops. Efficient land and water usage in irrigation regions requires processing of large amount of information, application of forecasting algorithms and decision making with uncertainty.

15 The expert system mentioned above is a part of a final version of decision support system for irrigation region in northern Mexico. The expert system recommends criteria for irrigation system management and simplifies the task of dispatchers, namely the task of real-time supplying of farms by required amount of water. The system contains:

- module for real-time irrigation calculation using automatic weather observing station,

- geographical information system,

- biological simulating program.

Information from groundwater balance module is used by the expert system which supports dispatchers in decision making which crop should be favoured in irrigation, minimizes the water loss and transforms information according to the user needs. It can be also used for locations with little data available.

HESSD

4, 1999-2033, 2007

Knowledge-based approaches for river basin management

P. Mikulecký et al.

Title Page

Abstract

Introduction

Conclusions

References

Tables

Figures

14

4

Back

Close

Full Screen / Esc

Printer-friendly Version

Interactive Discussion 
Data base contains data about irrigation region, such as weather, soils, crops, hydraulic control systems. Geographical information system creates and presents maps, optimizes water supplies, presents information about soil, channel and crop type. Information about crops and problems of each individual farmer can be easily retrieved.

Irrigation planning module simulates water requests according to the supply planned and real-time control. The evapotranspiration is calculated using temperature, relative humidity, wind speed, intensity of solar radiation and rainfalls (Penman-Monteith method). The biological simulation simulates crop behaviour based on soil, crop and weather data. Crop management, irrigation planning, fertilizer concentration, crop pro10 duction and harvest is also simulated; observed and simulated data are analyzed.

Calculation of the water balance in irrigation region uses data on crop and soil type, available soil water, irrigation, rainfalls and evapotranspiration. The balance calculation module forecasts water consumption for the following 10 days and supplies information on area irrigated which is used by the expert system.

The expert system was developed following the five steps of knowledge engineering: problem identification, problem formulation, knowledge acquisition and formalization, implementation and testing in Delicias (Chihuahua, Mexico) region.

\subsection{Expert systems for control}

Intelligent distributed control system was developed for pilot waste water treatment 20 plant with biological removal of organic matter, nitrogen and phosphorus (Baeza et al., 1998). The expert system was implemented in G2 intelligent development environment (Gensym, 2007). The expert system works on four levels: local control level, data level, distributed knowledge level and top supervisory level.

The lowest, local control level is the level of PLC (programmable logic controller) 25 programs which automatically control all mechanic equipments of the plant (pumps, level indicator, valves) including detection of operational failures and their correction. The values required can be set by the expert system directly.

Data level realizes real-time bidirectional data transfer between local control system 2011
HESSD

4, 1999-2033, 2007

\section{Knowledge-based approaches for river basin management}

P. Mikulecký et al.

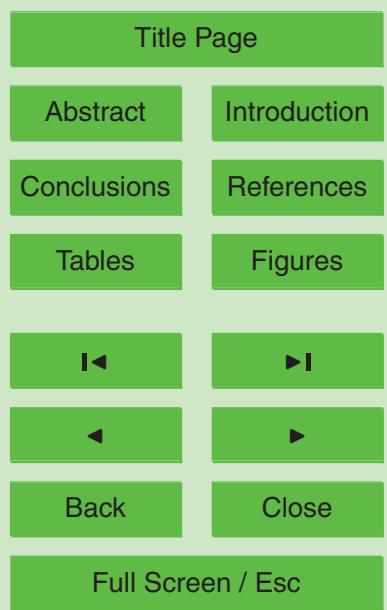

Printer-friendly Version

Interactive Discussion 
and expert system. Data transfer is performed using Internet connection. Data server of the plant sends properly formatted data to the expert system by e-mail. After receiving a structured e-mail, the expert system is able to update symbolic and numeric values of corresponding objects.

$5 \quad$ The distributed knowledge level is level on which several independent agents work. These agents control partial processes occurring in the treatment plant. The agents are specialized for e.g. bioreactor control, settling, pumping or feeding. Special agent monitors operation effectiveness, because in some situations the operation effectiveness has the biggest impact on the solution selection. Other agents control organic matter, nutrients and micro-organisms removal procedures.

At the top level a supervisory agent works. The supervisory agent decides whether to take a control action and supplies necessary information to subordinated independent agents. The supervisory agent also monitors complex operational parameters such that their calculation is based on information coming simultaneously from several agents. In case of problem situations, the supervisory agent requires confirmation from operation dispatcher for the optimal intervention formulation.

The supervisory agent ensures data exchange between the user and the expert system by means of user interface. The user interface offers graphical display of data and it includes explanation module as well. This module gives explanation on reasoning chain which was followed by the expert system in reaching solution.

The expert system was launched in testing mode for period of 400 days. During this time operational objectives changed repeatedly. The expert system proved its ability to control the pilot waste water treatment plant. It detected malfunctions correctly and suggested corrections in situations such as failure of valve or feeding problems. It worked reliably under special conditions as well, for example during maintenance of plant equipments.
HESSD

4, 1999-2033, 2007

\section{Knowledge-based approaches for river basin management}

P. Mikulecký et al.

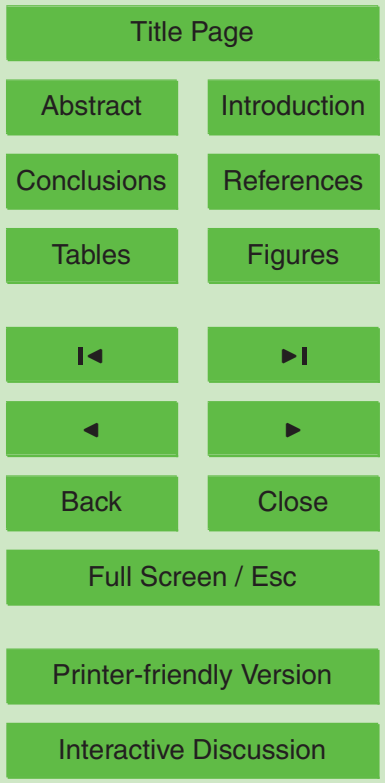

EGU 
Real-time intelligent system for decreasing the frequency of false fire alarm on open areas is reported by (Arrue et al., 2000). The system implementation includes infra-red computer vision, neural networks and fuzzy expert decision rules. The infra-red tech-

5 nology is suitable for early fire detection because it works with short time delay, good resolution and rather exact localization of fire. Its disadvantage is high frequency of false alarm caused by infra-red radiation of other sources. Infra-red detection systems usually can not process image information.

The intelligent system combines information coming from several sensors with ex10 pert knowledge in order to decrease frequency of false alarms. Identification of alarm as false or real one is done by three tools: sensor interface, image processing and decision function.

The sensor interface supplies images from visual and infra-red images cameras, meteorological information and numeric data which characterize the area being observed.

15 The sensor interface enables also real-time access to database of geographical information on topography and usage mode of the observed locality.

The processing of infra-red and visual image leads to alarm generation, if the infrared image has some statistical properties. The alarm is filtered out as false one, if a movement can be observed on the image, and therefore moving object can be identified as infra-red radiation source. Alarms with non-oscillating image are excluded as false alarms, too, because in the case of fire the flame flickering appears as changes in image shape and intensity within short time intervals, but heat radiation of hot stones is constant within short time. Visual image processing locates regions selected by infrared analysis on visual image. After that past alarms in these regions are searched and fire probability is estimated using meteorological data (temperature, humidity of air).

Fuzzy decision function works with results of the infra-red and visual analyses. If the region showed changes in time (oscillations), then fire is concluded with high degree of certainty as cause of the alarm. If the region of an alarm was bigger than region of

\section{Knowledge-based approaches for river basin management}

P. Mikulecký et al.

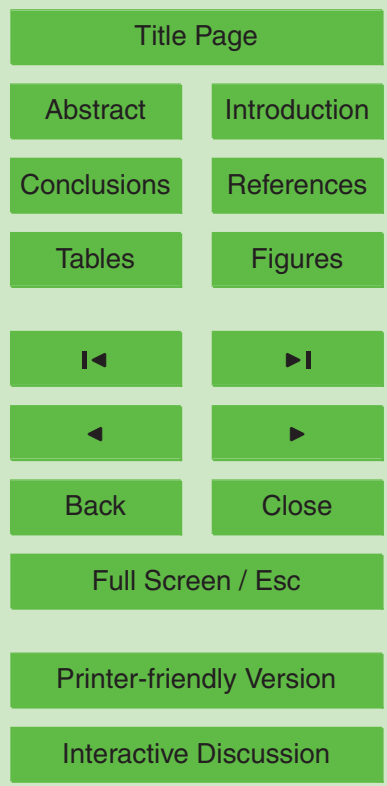

EGU 
previous alarms, then the certainty measure of fire is high. Fire risk index is calculated from meteorological and topographical information. Combination of this knowledge is captured in the form of fuzzy rules which calculate certainty measure of fire. This value represents attention measure for operator, telling him how much attention he should 5 pay to the alarm.

The system for false fire reduction was tested in the Centre for fire forest protection of Los Alcornocales reservation (Spain). Less than $2 \%$ of total number of false alarms was incorrectly identified as real alarm. All real forest fires were correctly identified as fires.

\section{Project Aquin}

The development in advanced countries has aimed to optimize their control of water resource management by artificial intelligent methods. The utilization of computers and robotics applications has been supported. The software preparation and verification of the intelligent support of the decision making process of dispatchers in complex sys15 tems has to be very realistic. The control of these systems requires processing of large amount of data, operational knowledge and experience. It means the development of expert or knowledge-based systems. Until now, progressive methods have only been asserted in practice, leisurely and with difficulties, in the Czech Republic, but good assumptions have been created for their application.

20 For example, companies managing river basins have already put into operation semiautomatic information systems for the data collection and transmission back to dispatch centres. Additionally they are preparing these information systems for real-time operation. However, these water management applications of expert systems are still rare in the country.

25 The three-year long project AQUIN was funded by the Grant Agency of the Czech Republic and was finished by December 2003. The objective of the project was to investigating possibilities of using knowledge technologies in the field of control and opti-
HESSD

4, 1999-2033, 2007

\section{Knowledge-based} approaches for river basin management

P. Mikulecký et al.

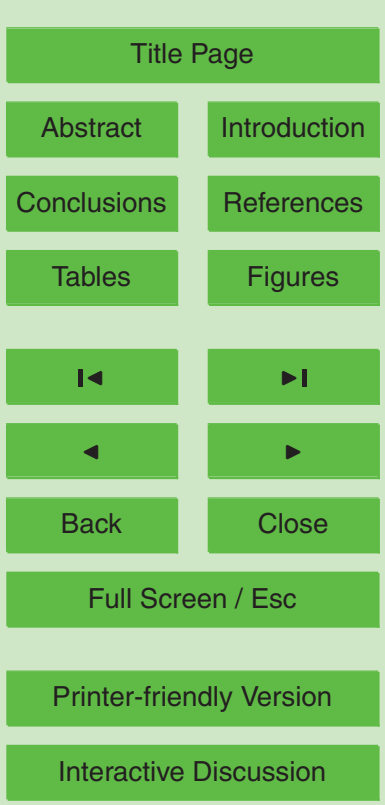

EGU 
misation of water management elements operation in real time water reservoir control in conditions of a Czech river basin management company. The partners of the project were the Czech Technical University from Prague, the University of Hradec Králové and Povodí Vltavy, a water management company from Pilsen. It was intended to take into 5 account such parts of knowledge life cycle as knowledge creation or knowledge acquisition, as well as knowledge organization and storage in suitable knowledge-based systems or their knowledge bases. The main knowledge processes in water management were analysed and certain methodical procedures for these processes were formulated and tested. As the goal of the project was an expansion of expert systems, 10 these methodical procedures were believed to substantially help in achieving this goal. The final main outcome of project was a model of a knowledge-based application that will help dispatchers at the dispatching centre of the company to formulate more accurate decisions about manipulations on the river basin reservoir.

\subsection{Problem definition}

15 Particularly, the objective of the project was development of a system that could help dispatchers who make decisions about the most suitable manipulations on the reservoir Nýrsko and on the river Úhlava in South-western Bohemia (see Fig. 1). Although the reservoir Nýrsko is relatively small (approximately $1400000 \mathrm{~m}^{2}$ ) and the river Úhlava is no longer than $110 \mathrm{~km}$, the problem of reservoir and river control is interesting enough, 20 because Nýrsko is the only resource of drinking water for over 180000 inhabitants of Pilsen. As this resource of water lays $100 \mathrm{~km}$ up on the stream from Pilsen, the task of effective and economical manipulations is non-trivial. The main obstacle comes from the time delay between the manipulation on the reservoir and the manifestation of the manipulation in Pilsen (3-7 days). That is why all requirements for reducing 25

or increasing of the consumption of water from the river Úhlava have to be defined in advance. In the same time the weather forecasts for several next days have to be taken into account in the process of manipulation formulation, because rainfalls or dry periods can radically change the flow rate in the river and its inflows and thus the significance

\section{HESSD}

4, 1999-2033, 2007

\section{Knowledge-based approaches for river basin management}

P. Mikulecký et al.

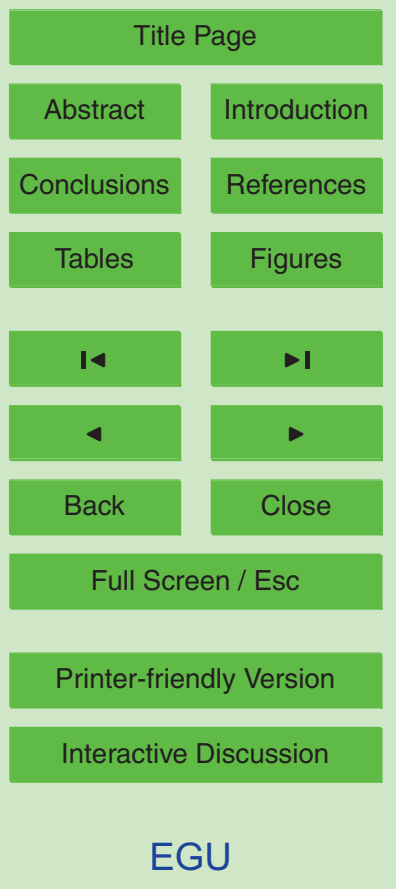


of manipulations gets even clearer. The other kind of obstacles is related to the pursuit of contradictory requests of different customers of the water management company, namely owners of electricity power plants, fishers, managers of water sport events, industrial companies that consume water from the river Úhlava etc.

\section{$5 \quad 4.2$ Knowledge sources in the company}

The domain knowledge analysis was essential for the development of a demonstrator of knowledge application. The knowledge analysis was carried out in two steps. Firstly, the project team had to find suitable ways of communication with water management experts who provided the domain knowledge, then the main effort was focused on the development of ontology, the representative vocabulary of problem domain. When the ontology was created, next steps were aimed at knowledge processes modelling according to the CommonKADS methodology (Schreiber et al., 2002). Following the creation of the model, a demonstrator of possible knowledge application was implemented.

15 An effective exploitation of knowledge and experience specific to water management requires identification of particular knowledge sources. The identification is closely related to a so-called knowledge audit of the water management company, that is, a throughout examination of what type of knowledge is available, what other knowledge may be needed and where to obtain it. For those types of knowledge where the audit shows their accessibility (in a documentation, manipulation guides, experiences of a concrete person disposed to formulate and hand over his/her knowledge to the project investigators, etc.) a collection process may immediately be started. They are written down using an appropriate formalism and stored in a systematically developed knowledge base where they can be explored and used at any time. For those types of

knowledge that will be indispensable in the proceeding solution but at the same time they will not be accessible in any of available sources, an external source will have to be identified and a negotiation on knowledge acquisition will become necessary.

In order to make use from knowledge related to the Úhlava river basin management,

HESSD

4, 1999-2033, 2007

\section{Knowledge-based approaches for river basin management}

P. Mikulecký et al.

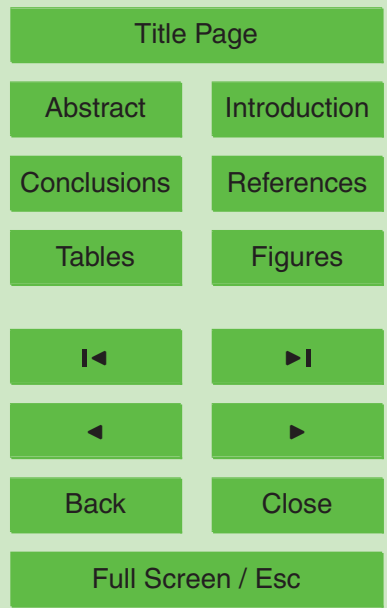

Printer-friendly Version

Interactive Discussion 
it is inevitable to identify particular sources of necessary knowledge. The knowledge sources relevant to the problem domain, to the problem itself and to the project AQUIN cover knowledge of variable relevance, profundity, availability and reliability. Keeping in mind the objectives of the project we should put difference between important, mod5 erately important and unnecessary types of knowledge, e.g. water quality parameters and historical measurements. Important types of knowledge gradually gained at their importance as the work on the project proceeded and the objectives of the project were eventually broadened. The moderately important types of knowledge may also become important in the case of modification of the project goals.

10 An important factor is the reliability of the knowledge sources used, as well. The majority is fully reliable, containing complete and correct measurement series, although, some pieces of data may be missing or misrecorded when transferred from one recording medium to another one. Still large part of knowledge is uncertain, to mention e.g. weather forecasting and operators' heuristic knowledge. On the other hand, the operators' heuristic knowledge is the most valuable knowledge that should be the essence of any developed knowledge system.

Therefore the task of capturing this kind of knowledge was one of the most difficult and the most important tasks, related to the AQUIN project.

\subsection{Existing practices in knowledge dissemination in the company}

20 The current practice in the storage of the operational knowledge inside the river basin company Povodí Vltavy was multifolded and there was no unique strategy on knowledge management that would also include its storage.

The knowledge in the form of data was mainly stored as discrete or continuous historical data on paper. Actually, the AQUIN project was an impulse to transform data 25 recorded manually or by an analogue device into digital records. Some data (e.g. forecasting, coming on the day basis) are not stored at all. However, these data might be an additional source of knowledge better characterizing the circumstances and factors that impact the operators' decision making. As these data were supplied by third par-

\section{HESSD}

4, 1999-2033, 2007

\section{Knowledge-based approaches for river basin management}

P. Mikulecký et al.

Title Page

Abstract

Introduction

Conclusions

Tables

References

Figures

14

$\rightarrow 1$

4

Back

Close

Full Screen / Esc

Printer-friendly Version

Interactive Discussion 
ties, a legal constraint in their storage might exist. Small part of data was automatically read at checkpoints and stored in an electronic file.

General operating rules and suggestions were stored as a paper look-up tables and graphs; no decision-support system was used. The heuristic knowledge of operators 5 was not stored at all. In no way it was captured and the company runs a risk that if an operator retired his expertise is lost.

An important aim of the project was to make the resulting decision support system as transferable as possible for a future usage at a similar problem within the domain for other beneficiary subjects. Therefore separating the storage of general and problem specific knowledge was important.

\subsection{Knowledge acquisition process in the company}

At the first meeting with the personnel of the company, we learned the basic principles about the operation of the river, responsibility delegation at various decision levels and possible actions that can be taken to control the reservoir. We also observed the river and the reservoir system including its control system ien situ. Afterwards we explored general textbooks related to the problem domain and the sources of codified specialized knowledge from materials given at the first meeting. We held several internal meetings to organize, clarify, and settle down the gained knowledge. In the following, we reformulated the transferred knowledge on our own and pointed out unclear issues.

20 A functionality proposal was set and directions of further knowledge acquisition were agreed upon.

Then we had an important meeting with operators of long experience in operating the reservoir Nýrsko and predicting the behaviour of the river and its ecosystem. This meeting was followed by a series of visits of dispatchers' workplace as it was important to observe how the operators decide in real situations.

HESSD

4, 1999-2033, 2007

\section{Knowledge-based approaches for river basin management}

P. Mikulecký et al.

Title Page

Abstract

Introduction

Conclusions

Tables

References

Figures

14

$\rightarrow$

4

Back

Close

Full Screen / Esc

Printer-friendly Version

Interactive Discussion 


\subsection{Problem analysis according to CommonKADS methodology}

While first knowledge-based applications were based on simple architectures with only one kind of knowledge representation, nowadays these systems use more ways for knowledge representation with the aim to come near to the human way of thinking 5 and human manipulation with information and knowledge. Of course, a more complex knowledge representation asks for deep methodologies. One of the most sophisticated knowledge modelling methodologies is CommonKADS (Schreiber et al., 2002).

CommonKADS explains how to model knowledge application through a structural top-down analysis of a problem domain. The outcome of modelling process according

to CommonKADS consists of three layers that are called contextual model, conceptual model and design model. Here, we present the model for the task managing water reservoir Nýrsko and we point out our investigations.

\subsubsection{Contextual modelling}

At the beginning of the knowledge-based system development, knowledge engineers 15 focus on the detection of obvious problems and interesting opportunities in the domain. In our task, we uncovered five basic problems with respect to the management of the Nýrsko reservoir:

1. Unsatisfying treatment of drinking water is the key problem. As the manipulation formulation is never based on a complete, but on available information only, it can be said that all decisions could have been done better. Unfortunately, the evaluation of decisions can be completed afterwards only.

2. Lack of balance of dispatchers' decisions is due to the fact that more dispatchers participate on decisions during the time and having different experiences and opinions, they do not make the same decisions, what disables any effort to detect the best way of managing reservoir by mining historical manipulations data.

\section{HESSD}

4, 1999-2033, 2007

\section{Knowledge-based approaches for river basin management}

P. Mikulecký et al.

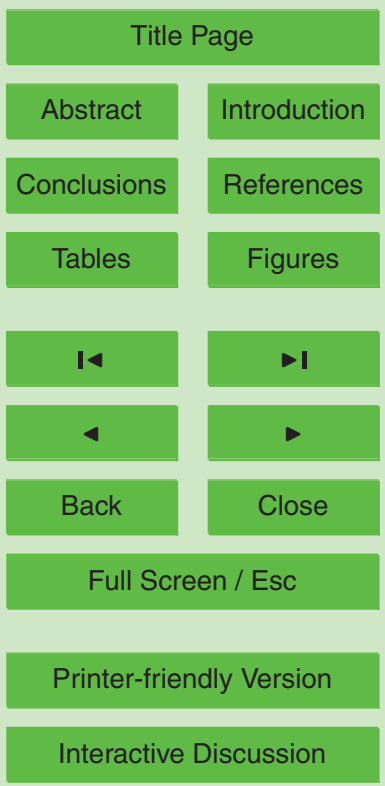

EGU 
3. Low use of water power plant happens, when water is lost by ineffective manipulations and then turbines of small hydropower plant on Nýrsko cannot be utilized optimally.

4. Technical insufficiencies in delivering data were detected by dispatchers themselves as the main reason of incorrect decisions. Some problems with missing data relate to the network of measurements points, which is not dense enough. Other data obstacles come from the fact that the water management company does not spend more money on buying data from providers. In some cases data are temporarily unavailable because of technical problems.

5. Out-of-date reservoir managing instructions (dispatcher's guide) cannot be detected easily, because these materials are said to be correct theoretically. Practically, they are evaluated and modified every five years, yet the modifications are usually not based on analysis of manipulations in the previous period.

With respect to problems mentioned above, the most interesting opportunities identified 15 in the field were:

1. Better data and information covering of the basin or buying wider spectrum of data from providers would help dispatchers to make more accurate decisions.

2. More economical manipulation with water would allow the company to supply water to more customers.

3. Suitable manipulations can improve the quality of water in the river Úhlava.

4. Knowledge-based application can increase the potential of sharing knowledge by dispatchers. The system containing the specific knowledge about the manipulation on the current river can serve as a tool for rapid training of newly coming dispatchers, either from different brands of the company, or graduates. All dispatchers, beginners as well as experienced employees, can use the system for consultations at any time they need.

HESSD

4, 1999-2033, 2007

\section{Knowledge-based approaches for river basin management}

P. Mikulecký et al.

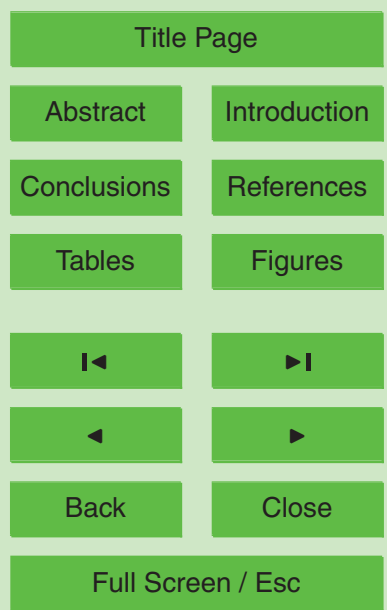

Printer-friendly Version

Interactive Discussion 
Among problems and opportunities, only those are important for us that are interesting from the knowledge-engineering point of view. It means we deal only with problems 1 , 2 and 3 and opportunities 3 and 4.

Problems and opportunities appear in relation with knowledge processes that are 5 in CommonKADS analysis divided into tasks and subtasks. Tasks are ordered in certain sequences. Inputs, outputs, knowledge sources, importance, responsibilities of subjects and time limits are defined for each task.

The process of managing water reservoir is described as a sequence of periodically repeated two basic dispatchers' tasks: (1) creation of an internal representation of the 10 current river basin situation and (2) manipulation formulation. In the task (1), the dispatcher collects data and creates his or her internal representation about the situation around the river Úhlava. The inputs of the task are tangible (data from measurements on the river basin, weather forecasts) and intangible (dispatcher's previous internal representation of situation). In the task (2), the internal representation of the situation in most suitable one. Other subjects in the system fulfil side tasks whose objectives are mainly delivering of data and information to dispatchers.

Tasks operate with information objects. Each information object is either input to or output of the task. We identified these information objects:

- Reservoir states are represented by records in the dispatcher's diary. Records consist of fields as water level in the reservoir, outflow rate, water temperature in the reservoir and at the bottom outlet, air temperature, rainfalls over last $24 \mathrm{~h}$, snow thickness, ice thickness, description of failures of turbines over last $24 \mathrm{~h}$, transparency of the water etc.

- Manipulations on the reservoir are described by three fields in the dispatcher's diary in terms of set-up outflow rates and times of manipulations.

- Historical records are composed of the current reservoir state and manipulations records that were moved to archive.

\section{HESSD}

4, 1999-2033, 2007

\section{Knowledge-based approaches for river basin management}

P. Mikulecký et al.

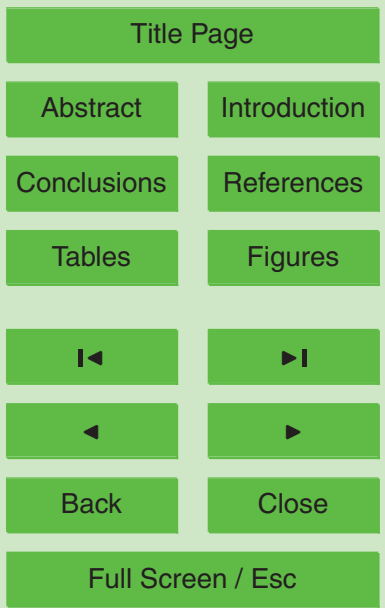

Printer-friendly Version

Interactive Discussion 
- State of weather on the reservoir contains information from the reservoir operator. This information object is not stored anywhere. It is information delivered during the communication between the dispatcher and the operator. The state of weather is characterized by the intensity of rainfall and the state of the sky observed above the reservoir Nýrsko.

- State of the river basin consists of data obtained from Czech Hydrometeorological Institute $(\mathrm{CHI})$. Standard set of data contains: river levels, flow rates and rainfalls measured on three points along the stream of the river Úhlava, estimated saturation of the river basin above the reservoir and estimated amount of water in snow (in winter times).

- Weather forecast from $\mathrm{CHI}$ embodies forecasted values of rainfalls in the region during next 24 hours and optional warning messages about possible extreme rainfalls and extreme increasing of water levels.

- Weather forecast from media represents a special kind of information occasionally used by dispatcher. It summarizes facts randomly picked-up from TV shots, weather forecast in newspaper etc.

- Weather forecast from Wetteronline server is the information about the expected values of rainfalls in the region in next hours and days. The forecasted values for nearer or further future are received with different level of confidence.

- Manipulation requests are written requirements, where time, demanded flow rate and place along the river are specified. The requirements come from customers or from the directorate of the water management company.

- Operator's objections are technical statements about the reservoir, obtained by dispatcher from the operator on the reservoir during the every-morning phone call. The manipulation formulation usually respects these objections.

HESSD

4, 1999-2033, 2007

Knowledge-based approaches for river basin management

P. Mikulecký et al.

Title Page

Abstract

Introduction

Conclusions

References

Tables

Figures

14

$\rightarrow 1$

4

Back

Close

Full Screen / Esc

Printer-friendly Version

Interactive Discussion 
Dispatchers' knowledge about the manipulations on Nýrsko is the most important knowledge in the domain. In general, we can say that the dispatchers' knowledge is incomplete, empirical, heuristic, highly specialized and hard to transfer. Difficulties in treating this kind of knowledge represent the bottleneck in our effort to build the 5 knowledge-based system and at the same time it is the main challenge for us. We determined five types of dispatcher's knowledge:

- Knowledge about the reservoir and basin behaviour consists of observed or estimated principles that rule the reservoir and river in various conditions and their response to different events, for example how the saturation of river basin changes in dependence on the amount of rainfalls.

- Knowledge about weather is based on long-term observations of weather in local conditions. The conclusions of the observations are useful for dispatcher when he creates his internal representation of state of river basin.

- Knowledge about manipulations supports the task of manipulation formulation. A typical example is the rule that says how to perform manipulation steps when the outflow has to be changed by more than $1.5 \mathrm{~m}^{3} / \mathrm{s}$.

- Knowledge about dynamics of reservoir and river basin explains how manipulations affect the river basin characteristics. The knowledge is often used for calculation of the time delays of manipulation manifestation along the stream.

- Knowledge about image information processing helps dispatcher to process and understand the weather forecast figures.

\subsubsection{Conceptual modelling}

After the contextual modelling has provided the insight into the knowledge-intensive processes related to controlling water reservoir, the conceptual modelling can describe

these processes in deeper details. The conceptual model according CommonKADS
HESSD

4, 1999-2033, 2007

\section{Knowledge-based} approaches for river basin management

P. Mikulecký et al.

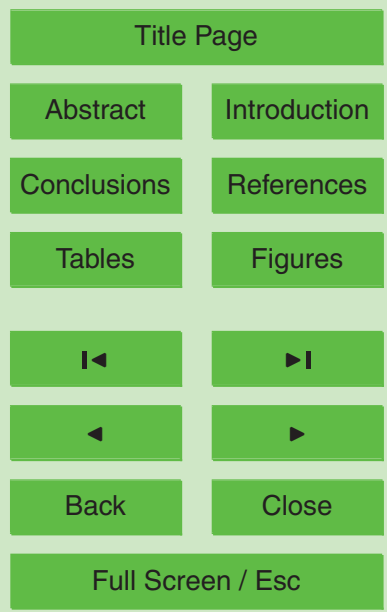

Printer-friendly Version

Interactive Discussion 
consists of three sub-models: domain knowledge model, inference knowledge model and task knowledge model.

At the beginning of project, kick-off meetings of the project team and water management experts showed that it is necessary to find a suitable communication platform.

5 Domain experts, who are dispatchers at the dispatching centre of the water management company, are used to talk and reason in specific terms. As their vocabulary reflects long-term experiences and knowledge in water management problem domain, they cannot simply share ideas with knowledge engineers and IT specialists. To overcome this communication barrier, it was essential to create ontology.

10 Ontology is defined as a common vocabulary of a domain that explains the meaning of concepts and their relationships. Briefly, ontology is a shared conceptualisation of the domain (Gruber, 1994). Nowadays, ontologies are popular because of their importance for the semantic web, where intelligent software agents can manipulate with content on the qualitatively higher level. Ontological engineering focused 15 on the development and maintaining of ontologies also gets into the main attendance of knowledge engineers and knowledge managers, who recognized that shared vocabularies enable automatic elaboration of knowledge-intensive tasks. Moreover, in early phases of knowledge projects, ontologies are a valuable tool that can support the process of acquiring, identifying, capturing and encoding knowledge (Jackson, 20 1999). For us, the ontology of water management domain was important. This ontology contains concepts such as river, river basin, reservoir, water-power-plant, manipulation-on-reservoir, saturation-of-river-basin, dry-period, water-pollution, traveltime etc. and relationships such as up-on-the-stream, inflowing-into, manipulation-on, sending-measurements-to etc. When dispatchers are used to talk using these concepts, the knowledge-based system has to manipulate with the same concepts.

One of the most important and pleasant characteristics of ontologies is that they can be shared and reused by systems and tasks. It means that we can try to find a suitable ontology that already exists and modify it with respect to our purpose. Reusing ontologies succeeds mainly in well-defined, specific domains. Unfortunately, concepts

HESSD

4, 1999-2033, 2007

\section{Knowledge-based approaches for river basin management}

P. Mikulecký et al.

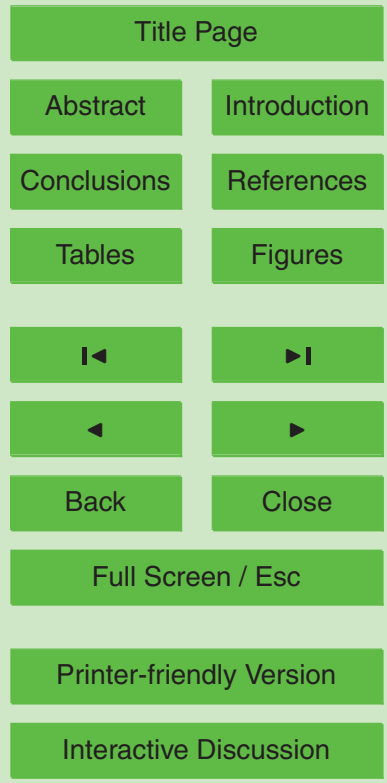

EGU 
of water managing domain do not all belong to the only ontology, but they appear in ontologies for weather forecasting, hydro-power plant managing, water consumption planning etc. Although the final set of concepts and relationships is small, completing it up from different ontologies would be hard (Gómez-Pérez, 1993). To avoid troubles 5 with merging various ontologies and checking them for completeness and correctness, we decided to create a special ontology for the project purpose. The ontology was written in Protégé2000 (Protégé website, 2007) editor and was built up from concepts we collected during discussions with dispatchers. The exact meaning of concepts was checked several times when the ontology was under the development, so the 10 consensus about concepts was achieved. Later, the ontology was consulted during the work on CommonKADS modelling of the system. The CommonKADS model operates only with those concepts and relationships that are parts of our ontology.

An important fact is that during the analysis of the domain we had to detect and catch significant differences between theoretical, strictly defined framework of the decision15 making processes and common behaviour of dispatchers.

For example, on one side there is a dispatcher's guide that strongly recommends the suitable manipulations to achieve the ideal curve of reservoir levels and volumes during the year and on the other side there are non-formalized, but practical reasons why the manipulations sometimes can not be based only on the official documents. We can illustrate this fact on a bit funny situation: on Nýrsko reservoir surface, there is a garage for the boat and this garage is anchored on ropes that would be cut across in case the level of water in the reservoir comes too low. In official documents this fact is not mentioned because the garage is not the regular part of the reservoir. When a higher level of water in the reservoir does not mean any danger (it even improves the quality

of water), dispatchers usually overcome the level recommended in the dispatcher's guide. Another, nowhere expressed, yet important rule says that an official rainfall forecast from $\mathrm{CHI}$ (CHI website, 2007), sometimes fails. German forecasts are more accurate and luckily they are published on German web server (Wetteronline, 2007), where the relevant part of South-western Bohemia is visualized in the same picture
HESSD

4, 1999-2033, 2007

\section{Knowledge-based approaches for river basin management}

P. Mikulecký et al.

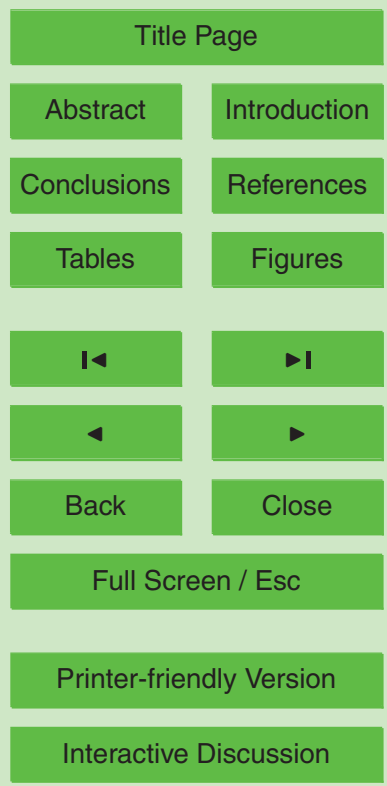

EGU 
with the forecast for Germany. That is why Czech dispatchers check German web page every morning, although they are supposed to use Czech forecast only.

Of course, to obtain information about this kind of dispatchers' experiences and skills is extremely hard as dispatchers are not ready to share them. In some cases, they are 5 not sure they can talk about such unofficial practices, or simply they do not believe this kind of informal rules is valuable for the system. Sometimes they do not even appreciate this type of their own skills and then, of course, knowledge engineer cannot take it into account.

Domain knowledge model simply refers to ontology. It clarifies concepts and rela10 tionships among them, orders and aggregates concepts into hierarchies, defines types of rules whose instances later appear in knowledge base. Inference knowledge model explains basic inferences above domain knowledge. Task knowledge model describes tasks and their methods. Tasks identified in the contextual model are here explained in terms of inferences and methods.

15 The conceptual model was developed in KADS22 (KADS22, 2007), a software tool for CommonKADS modelling. It is important to say that while creation of general rules is relatively simple, formulation of particular instances is difficult. Here, the consensus of all experts is necessary, but usually it cannot be easily achieved. The validation of rule instances in knowledge base often takes months and it cannot be finished before the full implementation of application, because only when the application is in use, the correctness of knowledge base can be checked definitely.

\subsubsection{Design model}

According to CommonKADS methodology of knowledge-based application development, the last model to be developed is design model. The design model has to reflect

various low-level implementation details, e.g. data exchange with the dispatching centre. At the time of project duration the data were processed mainly manually: they were acquired using telephone, by watching TV or face-to-face communication with weather forecasters. Therefore we chose not to elaborate implementation details until

\section{HESSD}

4, 1999-2033, 2007

\section{Knowledge-based approaches for river basin management}

P. Mikulecký et al.

Title Page

Abstract

Introduction

Conclusions

Tables

References

Figures

14

$\rightarrow 1$

4

Back

Close

Full Screen / Esc

Printer-friendly Version

Interactive Discussion 
data were manipulated more automatically. We focused on identification of all obstacles in automated information management which questioned meaningfulness of design model development. We formulated some guidelines how to make data and information processing more suitable for knowledge-based application and more help-

5 ful for dispatchers themselves. It is clear that by processing automatically more data and information, less important information is getting lost and more knowledge can be discovered in archives, databases and repositories.

\subsection{Demonstrator}

Although the development of prototype or even of full application still was not possible, we implemented reduced functionalities of the future knowledge-based system in a so-called demonstrator. This illustrative application helped to clarify and visualize the possibilities of knowledge application for its potential users. The useful effect of the demonstrator was that users obtained more confidence in the project effort. This effect was rather important as, in general, knowledge projects often fail because of the lack of confidence or lack of cooperation with people the system is primarily intended for.

The demonstrator was implemented as two separate applications in two different environments. The first part was created in G2, a powerful expert system development tool from the Gensym Corporation, and the second part of the demonstrator was built in CLIPS, an academic rule-based system offered by the NASA (National Aeronautics 20 and Space Administration).

The demonstrator in G2 was focused on implementation of various kinds of user interfaces that have to be as friendly as possible and that have to suit users' needs in terms of fast and comfortable access to main functionalities. A wide palette of $\mathrm{G} 2$ tools was used to achieve this goal. The demonstrator was able to manipulate with common

kinds of historical and current data accessible to dispatchers, e.g. records from the measurement points on the river stream. These records were presented in graphs and tables that correspond to the dispatchers' demands. Simple interactive elements were added and procedures for managing users' inputs were written, so the demonstrator

\section{HESSD}

4, 1999-2033, 2007

\section{Knowledge-based approaches for river basin management}

P. Mikulecký et al.

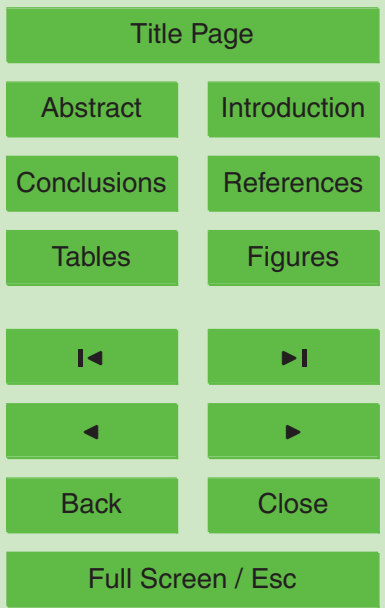

Printer-friendly Version

Interactive Discussion 
was able to simulate the reservoir behaviour, when the values of inflow, outflow, rainfalls etc. were input. The simulation displays informative or warning messages when significant states of reservoir are detected.

The second part of the demonstrator was implemented in CLIPS. The development 5 environment offered powerful inference engine able to operate with fuzzy-logic, while it allows programmers to create rather limited user interfaces. Here, we wrote several functional modules for demonstration of possible reasoning processes performed by the knowledge system in the field of water management. The demonstrator was equipped with various kinds of knowledge assets: dispatcher's graphs and guides nec10 essary for the manipulation formulation, tables of characteristic lines of Nýrsko reservoir, simple calculation and evaluation procedures that are applied on upcoming data, rules for conversion of numerical values to linguistic ones and so on. Having such knowledge, the demonstrator was ready to search for historical reservoir records according to certain parameters (e.g. extreme daily accumulation in the reservoir, long

\subsection{Summary of Aquin results}

Our knowledge analysis reflected the long-time trends in managing water reservoir. The amount of water demanded by customers interestingly had changed during the time. While 20 years ago the continuous growth of water let-offs from the river was expected, changes in the industry in the Czech Republic during the last two decades signalise that ensuring higher flow is not necessary and nowadays the official let-offs are going down systematically. Also a small water power plant was built on Nýrsko reservoir, which asked for changes in dispatcher's decision making about manipulations on reservoir opposite to previous practice.

25 Short-, middle- and long-term changes of claims make dispatchers to manipulate differently on the reservoir. A good way how to adapt manipulation decisions to new conditions is to use decision support system for modelling and simulating decisions or for retrieving information about previous manipulations and their consequences. The
HESSD

4, 1999-2033, 2007

\section{Knowledge-based approaches for river basin management}

P. Mikulecký et al.

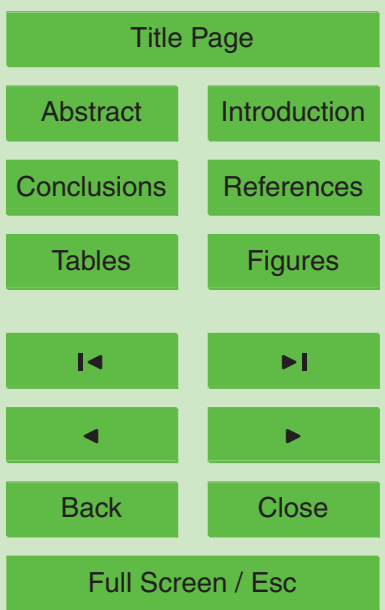

Printer-friendly Version

Interactive Discussion 
knowledge project AQUIN has shown that development of such application is possible.

The project team had to get the basic insight into the problem domain that is far away from common interests of most of team members, who are largely knowledge engineers and computer scientists. The elementary knowledge about the water manage-

5 ment domain and related problems were gained from interviews with domain experts (employees at the dispatching centre of water management company) and from recommended literature. The result of this first phase was the problem domain ontology. Later, the deep knowledge model was produced using CommonKADS methodology. The bottleneck of practical implementation of the application now lays in obtaining and 10 processing data and information automatically. When handling all upcoming data will be fully automated, the knowledge application can become very effective.

Some further descriptions of the knowledge-based system developed in the scope of the AQUIN project can be found in (Olševičová and Ponce, 2004).

\section{Conclusions}

15 We are deeply convinced that introducing knowledge management as well as other knowledge-based approaches into the area of river basin management could help substantially in solving many of the problems related to more efficient and effective operations in a number of important or even dangerous situations which appear in river basins. The effort still requires its further continuation, but our recent experience shows that the knowledge management approach based on much broader and more precise collection of relevant data, on careful acquisition and sharing of available and relevant knowledge, and on cooperation of all the river basin management staff in thorough exploitation of the shared knowledge could be a way to an ultimate goal - the knowledge-based river basin management.

25 Current project AquinPro that started in 2006 is aimed at investigation of further possibilities of knowledge-based systems utilization in the area of decision support in water management dispatch centres. The goal of the proposed project is to develop further
HESSD

4, 1999-2033, 2007

Knowledge-based approaches for river basin management

P. Mikulecký et al.

Title Page

Abstract

Introduction

Conclusions

Tables

References

Figures

14

$\rightarrow 1$

4

Back

Close

Full Screen / Esc

Printer-friendly Version

Interactive Discussion 
applications of knowledge-based technologies as well as knowledge management exploitation in the area of operational control of water structures. Based on the mentioned technologies, the solution of certain practical problems of the Povodí Vltavy company will be developed and enlarged further on. In the scope of the proposed project, the 5 experience already achieved will be applied on some other partial watersheds of the river Berounka. Particularly, the research is focused on

- investigating the case of several reservoirs (Hracholusky, Lučina), where the decision making is more difficult;

- deeper analysis of dispatcher's knowledge with respect to management of several reservoirs that influence each other;

- possible application of agent-based approach, either for simulations, or as a methodology of software development.

The new results are expected in 2008 and will be published broadly.

Acknowledgements. The research has been partially supported by the Czech Grant Foundation, Grant No. 103/06/1247 AquinPro.

\section{References}

Alonso-Betanzos, A., Fontenla-Romero, O., Guijarro-Berdiñas, B., Hernández-Pereira, E., Paz Andrade, M. I., Jiménez, E., Legido Soto, J. L., and Carbalas, T.: An intelligent system for forest fire risk prediction and fire fighting management in Galicia, Expert Systems with 20 Applications, 25, 545-554, 2003.

Arrue, B. C., Ollero, A., and Martinez de Dios, J. R.: An Intelligent System for False Alarm Reduction in Infrared Forest-Fire Detection, IEEE Intelligent Systems, 64-73, 2000.

Baeza, J., Gabriel, D., and Lafuente, J.: An expert supervisory system for a pilot waste water treatment plant, in: Proc. of ECAI 98 W7 Binding Environmental Sciences and Artificial
HESSD

4, 1999-2033, 2007

Knowledge-based approaches for river basin management

P. Mikulecký et al.

Title Page

Abstract

Introduction

Conclusions

References

Tables

Figures

14

Back

Close

Full Screen / Esc

Printer-friendly Version

Interactive Discussion 
Bukowitz, W. and Williams, R.: The Knowledge Management Fieldbook. Prentice Hall, London, 2000.

CHI (Czech Hydrometeorological Institute) website http://www.chmu.cz/, 2007.

CLIPS website http://www.ghg.net/clips/CLIPS.html, 2007.

5 Comas, J., Rodríguez-Roda, I., Sánchez-Marré, M., Cortés, U., Freixó, A., Arráez, J., and Poch, M.: A knowledge-based approach to the deflocculation problem: integrating on-line, off-line, and heuristic information, Water Res., 37, 2377-2387, 2003.

CommonKADS website http://www.commonkads.uva.nl/, 2007.

Cortés, U., Sánchez-Marré, M., and Ceccaroni, L.: Artificial Intelligence and Environmental Decision Support Systems, Applied Intelligence, 13, 77-91, 2000.

Dalkir, K.: Knowledge Management in Theory and Practice. Elsevier, Amsterdam, 2005.

Davenport, T. and Prusak, L.: Working Knowledge: How Organizations Manage What They Know. Harvard Business School Press, Boston, 1998.

Gensym website http://www.gensym.com, 2007.

15 Gómez-Pérez, A.: From Knowledge Based Systems to Knowledge Sharing Technology: Evaluation and Assessment. Technical Report KSL 93-04, Knowledge Systems Laboratory, Stanford University, 1993.

Gruber, T. R.: Toward Principles for Design of Ontologies used for Knowledge Sharing. Technical Report KSL 94-73, Knowledge Systems Laboratory, Stanford University, 1994.

20 Jackson, P.: Introduction to Expert Systems. Addison-Wesley, 1999.

KADS22 website http://hcs.science.uva.nl/projects/kads22/, 2007.

McElroy, M.: The New Knowledge Management: Complexity, Learning and Sustainable Innovation. Butterworth - Heinemann, Boston, 2003.

Meyer, M. and Zack, M.: The design and implementation of information products, Sloan Management Review, 37(3), 43-59, 1996

Mikulecký, P., Ponce, D., and Toman, M.: A knowledge-based decision support system for river basin management, in: River Basin Management II, edited by: Brebbia, C. A., WIT Press, Southampton, 177-185, 2003a.

Mikulecký, P., Ponce, D., and Toman, M.:A knowledge-based solution for river water resources so management, in: Water Resources Management II, edited by: Brebbia, C. A., Press, Southampton, 451-458, 2003b.

Mikulecký, P.: On the Way to Knowledge-Based Water Management. In: Hydrology: Science and Practice for the 21st Century, edited by: Webb, B., Acreman, M., Maksimovic,

\section{Knowledge-based approaches for river basin management}

P. Mikulecký et al.

Title Page

Abstract

Introduction

Conclusions

References

Tables

Figures

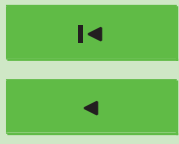

$\rightarrow 1$

Back

Close

Full Screen / Esc

Printer-friendly Version

Interactive Discussion 
C., Smithers, H., and Kirby, C., II, 434-438. London, British Hydrological Society, 2004.

Mundo, M., Martínez, P., Mireles, V., and Zazueta, F.: Expert systems for water management in irrigation districts. In: Applications of Artificial Intelligence in Engineering X. Computational Mechanics Publications 1995, Southampton, ISBN 185312316 1, 1995.

5 Nacházel, K. and Toman, M.: The genetic algorithm and its application to optimize energy utilization of a water reservoir, in: Applications of Artificial Intelligence in Engineering $\mathrm{X}$, edited by: Adey, R., Computational Mechanics Publ., 253-260, 1995.

Nacházel, K. and Toman, M.: The neural networks and their applications to optimize energy production of hydropower plants system, in: Applications of Artificial Intelligence in Engineering XI, edited by: Adey, R. A., Rzevski, G., and Teti, R., Computational Mechanics Publ., Southampton, 234-249, 1997.

Olševičová, K. and Ponce, D.: Knowledge analysis of the systems for water reservoir management. In: Hydrology: Science and Practice for the 21st Century, edited by: Webb, B., Acreman, M., Maksimovic, C., Smithers, H., and Kirby, C., II, London, British Hydrological Society, 2004.

Protégé website, http://protege.stanford.edu/ 2007.

Schreiber, G., Akkermans, H., Anjewierden, et al.: Knowledge Engineering and Management: The CommonKADS Methodology. MIT Press, 2002.

Toman, M. and Sedláček, Z.: Expertní systém a jeho aplikace při řízení složité vodohospodářské soustavy. Prezentace expertního systému pro dispečerské řízení vodohospodářské soustavy Povodí Odry. (in Czech) Workshop 96, Fakulta stavební ČVUT, Interní grant č. 2027, Praha, 1996.

Wenger, E., McDermott, R., and Snyder, W.: Cultivating Communities of Practice. Harvard Business School Press, Boston, 2002.

Wetteronline website http://www.wetteronline.de/, 2007.

Wiig, K.: Knowledge Management Foundation. Schema Press, Arlington, 1993.
HESSD

4, 1999-2033, 2007

\section{Knowledge-based approaches for river basin management}

P. Mikulecký et al.

Title Page

Abstract

Introduction

Conclusions

References

Tables

Figures

14

4

Back

Close

Full Screen / Esc

Printer-friendly Version

Interactive Discussion 


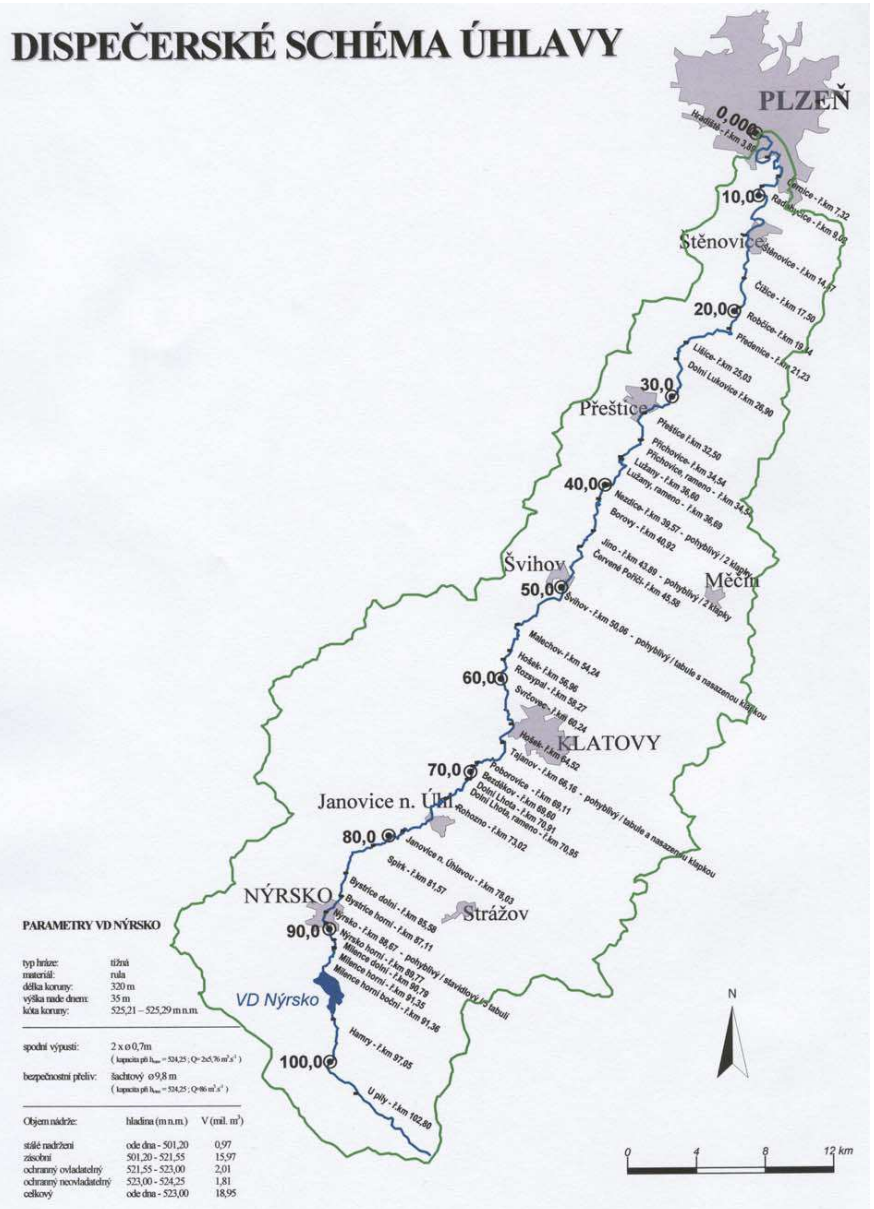

\section{HESSD}

4, 1999-2033, 2007

\section{Knowledge-based approaches for river basin management}

P. Mikulecký et al.

Title Page

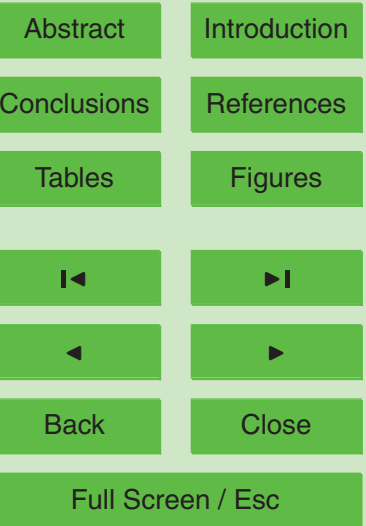

Printer-friendly Version

Interactive Discussion

Fig. 1. Map of Úhlava basin with water reservoir Nýrsko. 